\title{
EFFECTIVENESS OF PARENTING EDUCATION TOWARDS PARENTS ROLE IN GROWTH AND DEVELOPMENT OF PRE SCHOOL CHILDREN
}

\author{
Firdawsyi Nuzula 1), Rizky Dwiyanti Yunita 2), Vita Raraningrum 2) \\ 1)School of Nursing Diploma, Akes Rustida \\ 2)School of Midwifery Diploma, Akes Rustida \\ Corresponding e-mail : nuzulafirdawsyi@gmail.com, rizkydwiyanti8@gmail.com, \\ vitarara11@gmail.com
}

\begin{abstract}
BACKGROUND : the importance of early education in children has come to the attention of the government. If at that age the child's brain does not get maximum stimulation then all child development both physically and mentally will not develop optimally. Care has the aim to encourage the growth and development of children, both physical and psychological, parenting is also a process of interaction that is carried out continously between parents and children. The process of care cannot be separated from the influence of culture where the child is raised. Parents has important role which is begin since their child is in the womb untill they die to nurture their children. Profile of Banyuwangi District Health Service explain that there are $2.9 \%$ or 457 out of 15,762 ore school age children who experienced speech and language disorders. The purpose of this study was to determine the effect of providing parenting education on the development of pre school age children in PAUD 05 Klaibaru Cluster.
\end{abstract}

SUBJECT AND METHODE : this study is quasy experimental design conducted with pretest - post test group approach. The data anayzed by using chi square and wilcoxon sign rank test to determine the differences before and after treatment for both control group and experimental group.

RESULT : the result show obtained from chi square test show $p$ value of 0.05 which mean that parenting has significant effect toward independency and emotional regulation skill to pre school children. Although when compared between pre and post results is not too different.

CONCLUSION : Parenting is a reflection of parent in caring for, raising, caring for and educating children directly so that children become independent in learning.

Key words : character building, parenting, pre school children

\section{INTRODUCTION}

Parenting is a process that brings the final result, protect ang guides to a new life, provides basic resources, love, attention and values. Parenting has the aim to encourage the growth and development of childre, both physical and psychological. Parenting is also a process of interaction that is carried out continously between parent and children (Erlanti et al, 2015). The process of care cannot be separated from the influence of culture where the child in raised. Parent playas an important role and that the function of that role start since the childs has not being born until the parents die to nurture their children in a better way. This process should involving all element like the familiy (especially the parent), teachers, student it self, and peers must support each other so that what is expected could be achieved optimally (Noeraeni,2017).

Unicef states that the high incidence of developmental disorders in children under five, especially motoric development is arrounf $27.5 \%$ or 3 million children experience motor development 
disorders. In Indonesia there are $16 \%$ of children under five experiencing intelligent impairment, and it is caused by brain developmental disorders (Ministry of Health, Republic of Indonesia, 2008). Banyuwangi District Health Office Profile explains that there are $2.9 \%$ or 457 out of 15,762 pre school aged children who experience speech and languange disorders (Health Office of banyuwangi District, 2015).

Parenting style determines how the child will groe and develop later, and the wise parents will influence the child to achieve balance in learning and reach maturity biologically and emotionally. But if the parent arent wise in performing parenting style it will bring wrong impact significantly. These make the child to have poor emotional regulation, difficutirs in adapting to a new environment and will experience some psychological problems when they are growing up.

Another opinion suggest that the basic character values that must be taught to children from an early afe are trustworthy, respectful and caring, responsibility, courage, sincerity, honesty, visionary, diligent, disciplined, having integrity and being fair. Character is formed through three stages, namely knowledge, implementation and habits. Children who have good knowledge may not be able to carry out according to their knowledge, and if they are not accustomed to being trained to do good (Suwartini, 2017).

Good character quality should be formed and fostered from an early age, because at that age is a critical age for the formation of children's character. A child is like an empty bottle with no stains at all, something that is poured into the empty bottle that will fill the the empty bottle. As the time flies children will meet, learn and do many things from what they see, touch, hear, smell and feel (Robiah, 2018).

Parenting children woul be ideal if carried out by both parents. The parents cooperate each other in provising care an education to their children so that they can monitor dan evaluate their children devepoment optimally. Parenting is areflection of parent in caring for, raising and educatong their children directly so that children become independent in learning. Something that can affect parenting are the back grounf of parents and teachers, such as parental education and economic status, teachers perception and parental perception of parenting. This study was conduct to determine the effect of parenting education towards development of pre school age children.

\section{METHODE}

This study is qusi experimental research, conducting with pretest - post test control group design. Independent variables is parenting education that was given thriug seminar and dependent variables are knowledge and parenting pattern. The study conducted in PAUD 5 Kalibaru and involving 46 of parents selected by simple random sampling. The intrument was tesyed for validity and reability by population outside the respondents which was conducted by pretest and posttest questionnaire. The univariate analysis were conducted using Chi Squar analysis while the bivariate analyisis were conducted by using Wilcoxon sign data test. 


\section{RESULTS AND DISCUSSION}

Based on the results of data collection conducted on PAUD 05 Kalibaru were analyzed by using chi square test to see the effect of parenting education towards the implementation of parents role iin growth and development of preschool age children. The results are listed in the following table

Table 1. Frequency Distribution of Respondents Based on The Knowledge

\begin{tabular}{llll}
\hline & Observed N & Expected N & Residual \\
\hline Less & 2 & 23.0 & $-21,0$ \\
Good & 44 & 23.0 & 21.0 \\
\hline Total & 46 & &
\end{tabular}

Based on the table 1 it is known that respondents with good knowledge level wes 44 respondents(95\%) and some them were has lack of knowledge.

Knowledge about parenting education could be accessed at school since the school is formal institution that involving teh interaction betweeb these two. The teacher will teach the students about maturity. The application of concepts of Parenting Education in everyday life is the best and most effective way. Parents is also play an important role in determining the education for their children since condition of family will affect the decion making about children's education. It also affected by the knowledge about children's higher education. The better parent knowledge about education it will push them to send their children to school to extend their children education, and it will make the children success in the future. Some of data finding shows that after getting involved in parenting education, the parents are expected to to apllied it at home and this knowledge is expected to be used py parents to prepare their children's education for tertiary education.

Table 2. Frequency Distribution of Respondnt Based on Parent's Perception of Growth and Development

\begin{tabular}{lccc}
\hline & Observed N & Expected N & Residual \\
\hline Less & 5 & 23.0 & -18.0 \\
Good & 41 & 23.0 & 18.0 \\
\hline Total & 46 & &
\end{tabular}

According to the data in table 2 it is known that respondent with good perception were 41 respondents $(89.1 \%)$. It is implied that mother already has good attitudes towards childrens growth and development.

Educational process are involving every one in the circumstance so that the teacher, students and parents should supporting each other to reach the goal optimally. Most of parents thought that education is teacher's responsibilities (Reskia, 2014). Inablity to understand children's need will triggers a conflict between the parents and children in parenting. Conflict arises as the parents belief that good or bad the children will be is parents responsibilty. Parents beliefe that if they nurturing their child in the "right" way the the children will become a perfect individual. Children behavior (adolescent) which become a dissident to the parents will and it was a failure in educating children (Missiliana, 2014).

The aims and advantages of positive parenting is helping the children to have a positive confident and love to their parents, harmonize the relationship of children and their parents through 
attention when then obey the rules, giving help and show some affection, and forming a discipline through consistent education accompanied by consequences from the parents. The main aims of parenting is helping the parents to set a comfortable and peaceful liveor their child and supporting their child to have high welfare and able to achieve life satisfaction so that their children will live in happiness. Nurturing in oarenting has some principal things whic are : (1) fulfillment of children's nutrition since nutrition has big impact to childrens development, consentration and other mental ability, (2) create a balance life where the children has same chance to play, learning and explore the environmet and having quality time with parents, (3) developing a safety and security in daily live to protect the child from the negative effect of environment, a situation not yet understood and create a positive environmet, (4) maintaining an open communication to the children, their friends, schools, and environment surround them, (5) being an active parents so that the children knows that they are loved, having a strong bonding and it will used as a reference for children to behave.

Table 3. Frequency Distribution of Respondents Based on Parent Perception of Parenting

\begin{tabular}{llll}
\hline & Observed N & Expected N & Residual \\
\hline Less & 12 & 23.0 & -11.0 \\
Good & 34 & 23.0 & 11.0 \\
\hline Total & 46 & &
\end{tabular}

According to the table 3 it is known that respondents with good parenting pattern are 34 rspondents $(74 \%)$. We can see that there is still some parents who have not delivered a good parenting to their child.

Authoritarian parenting is a parenting pattern where tha parents obtruding their children, nurturing the kids with some strict roles, force the children to behave like the parents and limit the child to behave at their own. Permissive parenting is the opposite of authoritarian parenting, focusing to the child where the child has board freedom so that there is no restriction on rule from the parents. Democratic parenting is signed by parents recognition towards children ability. Children are given chance to be independent. The parents always supporting the children to talk about what they want openly (Khaira, 2016).

Implementing parenting need an extra attention since parenting has an urgent role in creating children personality like the level activity of fine motoric development. Parenting is about how the parents understanding their child characteristics so that the children do not feel stressed at the raltionship with the parents. The parenting pattern chosen by the parents should adapting and understanding the children since every child is unique. There are some parents who threat their child in the same way for all the children. It will bring up oppsition from the children, complaining and the results will dissapointed (Sari, 2015).

Based on Chi Square analysis result it is showed that the $p$ value is $0.000<\alpha=0.05$ which mean that there are significant correlationship between knowledge, perceptionm and parenting education towards parents role on growth and development of children. 
Tabel 4. The Effect of Parenting Education towards Parents Role on the Growth and Development of Pre School Age Children

\begin{tabular}{|l|r|r|r|r|r|r|}
\hline & \multicolumn{2}{|c|}{ Test Statistics } & & post & & post pola \\
& pengetahuan & pre sikap & pre pola asuh & pengetahuan & post sikap & asuh \\
\hline Chi-Square & $25,130^{\mathrm{a}}$ & $10,522^{\mathrm{a}}$ & $5,565^{\mathrm{a}}$ & $38,348^{\mathrm{a}}$ & $28,174^{\mathrm{a}}$ & $10,522^{\mathrm{a}}$ \\
df & 1 & 1 & 1 & 1 & 1 & 1 \\
Asymp. Sig. &, 000 &, 001 &, 018 &, 000 &, 000 &, 001 \\
\hline
\end{tabular}

a. 0 cells $(, 0 \%)$ have expected frequencies less than 5 . The minimum expected cell frequency is 23,0 .

The result with significancy of $95 \%$ means that implemented parenting by the parents has significant effect to the in, adependency and emotional regulation ability of pre school age. The $p$ value of 0.000 mean $p$ value $<$ a 0.05.Parent role plays important part in the growth and developmental of pre school age children so that the child will be able to finish their assignment (homework), has a healthy competition, feel happy to gather arround with their peers and having a best friend, taking part in group activities. Parents as stimulator should direct the children to behave industry.

It is in line with the study conducted with Tuegeh, Rompas and rasun (2011) who stated that family role determine children independency even in children with mental retardation. At the same time family with little attention will slow down the independency of children with mental retardation. This argument is supported bu Purnomo (2013) which said that family role in optimize children growth and development to build children character.

\section{CONCLUSION AND RECOMMENDATION}

The result obtained from this study is parenting has significant effect toward independency and emotional regulation skill to pre school children. From those conclution, the reccoemend that the next study should explain deeply about children growth and development by using true experimental methode and observations are conducted continously in spesific range of time so that the impact of parenting will observe clearly and this training is also need to be shared with the the teacher.

\section{REFERENCE}

Bornstein, M. H. (Ed.). (2002). Handbook of parenting: Children and parenting (2nd ed.). Mahwah, NJ, US: Lawrence Erlbaum Associates Publishers.

Darosy Endah Hyoscyamina, K. S. (2012). Pengembangan Program ParentingBagi Anak Usia Dini Dengan Pendekatan Psikologi Positif Dan Karakter Islami. seminar nasional psikologi islami.

Depkes RI. (2008). Profil Kesehatan Indonesia 2006. Departemen Kesehatan Republik Indonesia. Jakarta, 2008. 
Dinkes Kab. Banyuwangi. (2015). Profil Dinas kesehatan kab.banyuwangi. Dinas Kesehatan Kabupaten Banyuwangi.

Fitriyah Hayati, Nordin Mamat. (2014) pengasuhan dan peran orang tua (parenting) serta pengaruhnya terhadap perkembangan sosial emosional anak PAUD banda aceh, indonesia. Volume 1 Nomor 1. September, 2014.

Kemendiknas.2011. Pedoman pendidikan karakter pada pendidikan anak usia dini, direktorat pembinaan anak usia dini, ditjen PAUDNI.

Johana Tuegeh, Frenny Rompas dan Djoni Ransum. (2012). Peran Keluarga Dalam Memandirikan Anak Retardasimental Di Yayasan Pembinaan Anak Cacat Manado Tahun 2011. Jurnal Jueperdo, vol 1 No. 1 Maret 2012.

Khaira, K. (2016). Melahirkan Golden Generation Melalui Golden Parenting. Proceeding International Seminar on Education 2016 Faculty of Tarbiyah and Teacher Training, 297.

Missiliana R, V. H. (2014). Identifikasi Parenting Belief Pada Remaja dan Orangtua di Kota Bandung : Pendekatan Psikologi Psikologi Indige-nous. Jurnal Psikologi, Volume 10 Nomor 2, Desember, 87.

Mutiara Suci Erlanti, Nandang Mulyana dan Hery Wibowo. (2015). Teknik Parenting Dan Pengasuhan Anak Studi Deskriptif Penerapan Teknik Parenting di Rumah Parenting Yayasan Cahaya Insan Pratama Bandung. Prosiding KS;Riset dan PKM Volume 3, Nomor 2; hal 155-291.

Rahayu, S. (2014). Pertumbuhan Dan Perkembangan Balita Di Posyandu Surakarta. Jurnal Terpadu IImu Kesehatan, Volume 3, No. 1, Mei 2014, Hal 88-92.

Reni Oktavia Sari. (2015). Hubungan Pola Asuh Orang Tua Dengan Perkembangan Motorik Halus Anak Usia 4-6 Tahun Di Tk Dharma Wanita Suruhan Lor Kecamatan Bandung Kabupaten Tulungagung, Jurnal IImu Keperawatan dan Kebidanan (JIKK), Vol. II, No. 3, Desember 2015.

Resiana Nooraeni. (2017). Implementasi Program Parenting Dalam Menumbuhkan Perilaku Pengasuhan Positif Orang Tua Di PAUD Tulip Tarogong Kaler Garut. Jurnal Pendidikan Luar Sekolah Volume 13 Nomor 2, Oktober 2017.

Soetjiningsih dan Ranuh, I.G.N Gede. (2013). Tumbuh kembang anak, edisi 2. Jakarta ; EGC.

Sri Reskia, H. Z. (2014). Pengaruh Tingkat Pendidikan Orang Tua Terhadap Prestasi Belajar Siswa, Di SDN Inpress 1 Birobuli. Elementary School of Education EJournal, Media Publikasi IImiah Prodi PGSD Vol 2, Nomor 2, Juni, 83. 